\title{
Pengembangan Modul Pelatihan Pedagogical Content Knowledge (PCK) Dalam Meningkatkan Kompetensi Profesional dan Kompetensi Pedagogik Guru Matematika SMP
}

\author{
Mega Wulandari \\ Magister Manajemen Pendidikan Universitas Kristen Satya Wacana \\ megaretno2503@gmail.com \\ Ade Iriani \\ Magister Manajemen Pendidikan Universitas Kristen Satya Wacana \\ ade.iriani@staff.uksw.edu
}

\begin{abstract}
The research objectives are to describe the training that has been held so far and its weaknesses and to develop PCK training modules in order to improve the pedagogical and professional competence of mathematics teachers. This type of research is research and development. The research subjects were the MGMP Coordinator and junior high school mathematics teacher. Data collection techniques are observation, interviews, documentation studies, and tests. Data analysis techniques use mixed methods. The PCK training module was developed using the Sugiyono model, taking 7 stages namely potential and problems, data collection, product design, design validation, design revisions, limited trials and product revisions. Module validation tests are carried out by module experts, PCK experts, and prospective users. Research results: 1) Training for junior high school mathematics teachers have been focused on the dissemination of the 2013 curriculum and PCK training has never been held; 2) The weakness of the training that has been held so far: material from the powerpoint print out presented by the speaker, when the training collided with teaching activities in the school, the training material was only about the 2013 curriculum; and 3) PCK training modules that have been developed are feasible to use.
\end{abstract}

Keywords: Junior High School Mathematics Teacher, Pedagogical Content Knowledge (PCK), Training Module

\section{Article Info}

\section{PENDAHULUAN}

Pedagodical Content Knowledge (PCK) atau pengetahuan konten pedagogik, pertama kali dikenalkan oleh Shulman pada tahun 1986. Menurut Shulman (1986:6) terdapat tiga dimensi pengetahuan profesional yang penting bagi seorang guru yaitu Subject Matter Content Knowledge, PCK (Pedagogical Content Knowledge), dan CK (Curricular Knowledge). Pedagogical Content Knowledge (PCK) merupakan salah satu pengetahuan dan elemen penting yang mutlak harus dikuasai oleh guru dalam rangka meningkatkan kualitas guru (Hanggara, 2015:1). PCK menurut Shulman (1986:9) merupakan kombinasi dari dua jenis kompetensi, yaitu kompetensi pedagogis (pedagogical knowledge) dan pengetahuan konten (content knowledge). Seorang guru harus menguasai dua pengetahuan dalam melakukan pembelajaran secara seimbang, 
Kelola: Jurnal Manajemen Pendidikan, Vol. 5, No. 2, Juli-Desember 2018

yaitu pengetahuan materi pelajaran dan pengetahuan pedagoginya (Resbiantoro, 2015:123). PCK sangat penting dimiliki oleh seorang guru untuk menciptakan pembelajaran yang bermakna bagi siswa. PCK menjadi isu sekaligus ide baru untuk memaksimalkan proses dan hasil pembelajaran, khususnya dalam pembelajaran matematika.

Seorang guru harus menguasai pengetahuan dalam melakukan pembelajaran secara seimbang, antara pengentahuan materi pelajaran dan pengetahuan pedagogi. Content Knowledge (CK) merupakan salah satu pengetahuan yang ada di dalam Pedagogical Content Knowledge (PCK). Content knowledge merupakan kompetensi profesional guru. Menurut PP No. 74 tahun 2008, kompetensi profesional adalah kemampuan guru dalam menguasai pengetahuan bidang ilmu pengetahuan, teknologi, seni dan budaya yang diampunya. Selain kompetensi profesional seorang guru juga harus memiliki kompetensi pedagogik. Menurut Aminah (2014:56) pengetahuan pedagogi merupakan jenis pengetahuan yang unik untuk guru dan didasarkan pada cara guru dalam mengajarkan apa yang akan diajarkan. Selain itu, Suminawati (2018: 3) berpendapat bahwa Pedagogical Knowledge (PK) berkaitan dengan cara dan proses mengajar yang meliputi pengetahuan tentang manajemen kelas, tugas, perencanaan pembelajaran dan pembelajaran siswa. Oleh karena itu, Pedagogical Knowledge (PK) sangat identik dengan kompetensi pedagogik guru.

Saat ini teknologi dan informasi berkembang dengan pesat. Sehingga, muncullah tantangan terkait penerapan teknologi dalam proses pembelajaran. Tantangan tersebut, tidak mudah dihadapi oleh guru, karena guru harus mampu menguasai teknologi dan menerapkan dalam proses pembelajaran. Untuk menjawab tantangan tersebut, sebuah kerangka teoritis penting yang muncul dalam penggunaan teknologi informasi dan komunikasi oleh guru saat ini adalah Technological Pedagogical Content Knowledge (TPACK) (Rosyid, 2016). TPACK merupakan sebuah kerangka untuk mengintegrasikan teknologi dalam mengajar (Koehler, Mishra, Ackaoglu,\&Rosenberg, 2013). Menurut Roysid (2016) Technological Pedagogical Content Knowledge (TPACK) berfokus pada 3 komponen utama yaitu konten, pedagogik dan teknologi.

Damawati (2015) berpendapat bahwa PCK merupakan faktor penting karena sangat berpengaruh terhadap proses pengajaran yang dilakukan guru. Untuk mengembangkan PCK guru dapat melalui program pelatihan yang tujuannya untuk menfasilitasi guru dalam mengembangkan PCK dan meningkatkan kesadaran terhadap prosedur mengajar dan pembelajaran. Untuk mengajar seorang guru tidak hanya cukup dengan berbekal memahami konten materi saja, tetapi juga harus mengetahui cara mengajarkan materi tersebut (Susilowati, 2015).

Penelitian ini hanya berfokus pada PCK seorang guru. Hal ini dikarenakan, beberapa guru matematika SMP di Kota Salatiga masih memiliki kendala terkait pemahaman terhadap materi matematika dan cara mengajar siswa dengan karakteristik yang berbeda. Selain itu, walaupun beberapa guru memiliki pemahaman yang cukup baik terhadap teori belajar, metode mengajar atau media mengajar, namun terkadang guru-guru masih kesulitan dalam mengimplementasi kan atau praktik mengajar. Sehingga mereka memiliki pola mengajar yang tetap, padahal tidak semua materi matematika dapat diajarkan kepada siswa dengan metode mengajar yang sama, karena setiap materi memiliki karakteristik yang berbeda-beda. Permasalahan tersebut menunjukkan bahwa PCK yang dimiliki oleh beberapa guru matematika di Kota Salatiga masih kurang, khususnya dalam pengetahuan materi dan cara mengajarnya. Oleh karena itu, perlu adanya usaha dalam mengembangkan PCK guru 
Pengembangan Modul Pelatihan Pedagogical Content Knowledge (PCK) ... | Mega Wulandari \& Ade Iriani

Matematika, sehingga dapat meningkatkan kompetensi pedagogik dan kompetensi profesional yang dimilikinya.

Menurut Shulman (1986:14), banyak faktor yang mempengaruhi PCK guru, diantaranya adalah : pengalaman mengajar (Teaching Experience), pelatihan (Training), sarana \& prasarana pembelajaran (Technology), efikasi diri (Self Efficacy) dan motivasi (Motivation). Pelatihan (Training) merupakan salah satu upaya untuk mengembangkan kemampu an dan meningkatkan kompetensi guru dalam melaksanakan tugas dan tanggung jawabnya.

Berdasarkan paparan tersebut, peneliti berupaya meningkatkan kompetensi pedagogik dan kompetensi profesional dengan cara mengembangkan modul pelatihan PCK. Aditia (2013:6) mengemukakan bahwa modul merupakan alat atau sarana pembelajaran yang berisi materi, metode, batasan-batasan materi pembelajaran, petunjuk kegiatan belajar, latihan dam cara mengevaluasi yang dirancang secara sistematis dan menarik, untuk mencapai kompetensi yang di harapkan dan dapat digunakan secara mandiri. Menurut Departemen Pendidikan Nasional (2002:21-26) satu modul dibuat untuk mengajarkan suatu materi yang spesifik supaya peserta belajar mencapai kompetetensi tertentu. Struktur penulisan suatu modul sering dibagi menjadi tiga bagian, yaitu bagian pembukaan, bagian inti dan bagian penutup.

Modul pelatihan PCK dikembangkan dengan model Sugiyono. Sugiyono (2010:407) mengemukakan bahwa pengembangan atau Research and Development (R\&D) adalah metode penelitian yang digunakan untuk menghasilkan produk tertentu, dan menguji keefektifan produk tersebut. Penelitian ini, hanya mengambil 7 (tujuh) tahapan yang dalam model Sugiyono. tujuh tahapan tersebut yaitu potensi dan masalah, pengumpulan data, desain produk, validasi desain, revisi desain, uji coba terbatas, dan revisi produk.
Penelitian berjudul "Pengembang- an Modul Pelatihan Pedagogical Content Knowledge (PCK) Dalam Meningkatkan Kompetensi Profesional Dan Kompetensi Pedagogik Guru Matematika SMP” ini bertujuan untuk a) mendeskripsikan pelatihan yang selama ini diselenggara kan, b) mendeskripsikan kelemahan pelatihan yang selama ini diselenggarakan dan c) mengembangkan modul pelatihan PCK untuk meningkatkan kompetensi pedagogik dan kompetensi profesional guru matematika SMP di Kota Salatiga.

\section{METODE PENELITIAN}

Jenis penelitian ini merupakan jenis penelitian pengembangan atau Research and Development (R\&D). Penelitian ini di lakukan di Kota Salatiga, Provinsi Jawa Tengah. Penelitian pengembangan ini menggunakan rancangan penelitian model Sugiyono dengan mengambil tujuh tahapan saja, dimulai dengan adanya potensi dan masalah, pengumpulan data, desain produk, validasi desain, revisi desain, uji coba produk terbatas, dan revisi produk. Teknik pengumpulan data yang di gunakan dalam penelitian ini yaitu observasi, wawancara, studi dokumentasi dan tes. Observasi dilakukan pada tahapan pelaksanaan pelatihan, untuk mengamati proses pelaksanaan pelatihan yang sedang dilakukan. Wawancara dilakukan untuk mendapatkan data mengenai pelatihan dan PCK yang dimiliki guru matematika. Studi dokumen digunakan untuk menambah dan melengkapi data yang di perlukan dalam penelitian ini, dengan cara membaca dan mempelajari dokumen-dokumen yang ada. Adapun dokumen yang dibutuhkan berupa profil sekolah dan dokumen terkait guru-guru yang mengajar matematika di setiap SMP, serta kajian teori mengenai PCK dan modul pelatihan. Tes dalam penelitian ini terdiri dari pre-test (sebelum pelatihan) dan post-test (setelah pelatihan) yang dilakukan pada fase implementasi atau uji coba produk 
Kelola: Jurnal Manajemen Pendidikan, Vol. 5, No. 2, Juli-Desember 2018

terbatas untuk mengetahui peningkatan kompetensi pedagogik dan kompetensi profesioanal peserta pelatihan setelah mengikuti pelatihan. Teknik analisis data dalam penelitian ini menggunakan metode campuran (Mixed Methods).

\section{HASIL PENELITIAN DAN PEMBAHASAN}

\section{Hasil Penelitian}

\section{Deskripsi Pelatihan Yang Pernah Diselenggarakan}

Pelatihan bagi guru-guru merupakan suatu kebutuhan yang penting. Selama ini, guru matematika pada jenjang SMP di Kota Salatiga, sering mengikuti beberapa pelatihan yang diselenggarakan oleh dinas pendidikan maupun MGMP. Untuk menggali informasi tentang pelatihan yang selama ini diikuti peneliti mewawancaral seorang koordinator MGMP untuk mapel matematika (YE), dan 2 (dua) orang guru matematika (RD dan BD) yang mengajar di SMP yang berada di wilayah Kecamatan Sidorejo, Kota Salatiga. Hasil wawancara dengan YE, RD dan BD menunjukkan bahwa pelatihan yang selama ini diikuti merupakan program pemerintah. Adapun program pemerintah selama 3 tahun terakhir ini adalah berkaitan dengan sosialisasi Kurikulum 2013. Pelatihan bagi guru mapel matematika pada jenjang SMP selama satu tahun terakhir ini rutin dilaksanakan oleh MGMP. Waktu pelatihan disesuaikan dengan materi pelatihan yang akan disampaikan. Peserta yang di undang sekitar 80 orang tetapi, yang merespon dan berpartisipasi biasanya hanya setengahnya saja. Tempat pelatihan biasanya di sekolah-sekolah yang ada ruangan atau gedung yang luas untuk dapat digunakan sebagai tempat pelatihan. Peserta pelatihan diberi materi pelatihan yang akan dipaparkan oleh pembicara, biasanya berupa print out Power Point materi ataupun modul jika ada. Tindak lanjut dari pelatihan berbeda-beda, misalnya dalam pelatihan Kurikulum 2013 nantinya guru-guru dituntut untuk membuat RPP Kurikulum 2013 dan nantinya ada tim yang mendampingi saat mengimplementasikan nya di dalam kelas.

Berdasarkan hasil wawancara, masih terdapat beberapa guru dengan pratik mengajar yang belum baik. Guru-guru mengetahui dan paham akan teori belajar, metode pembelajaran maupun pendekatannya. Tetapi, di dalam mewujudkannya ke dalam praktik mengajar masih kesulitan. Tidak semua materi matematika, bisa menggunakan pendekatan atau metode pembelajaran yang sama, dan masih ada guru yang memaksakan materi tertentu yang sebetulnya tidak cocok dengan metode yang dipilihnya. Hal ini, biasanya dikarenakan guru-guru hanya berpatokan pada buku ajar saja. Padahal penguasaan materi sangat berpengaruh terhadap pemilihan dan penentuan metode ataupun pendekatan yang akan digunakan pada materi tertentu.

Hasil wawacara dengan RD dan BD menunjukkan bahwa kedua guru ini pernah mengikut pelatihan yang diselenggarakan oleh MGMP. Tetapi, tidak semua kegiatan pelatihan yang diselenggarakan oleh MGMP mereka ikuti. Hal itu karena waktu pelatihan bertabrakan dengan waktu kegiatan di sekolah ataupun ada beberapa hal yang tidak dapat ditinggalkan. YE juga berpendapat bahwa setiap guru memiliki kebutuhan dan zona yang berbeda-beda, sehingga menyebabkan guruguru tidak aktif dalam pelatihan.

Berdasarkan hasil wawancara dengan YE, RD, dan BD selama ini belum pernah ada pelatihan yang berkaitan dengan PCK. RD dan BD mengatakan bahwa belum memahami ataupun mengerti apa itu PCK. Berdasarkan hasil wawancara dengan YE yang menyatakan bahwa jika diselenggarakan pelatihan mengenai PCK sangat bermanfaat bagi guru, dimana PCK merupakan perpaduan di antara pengetahuan materi dan pengetahuan cara mengajar. Hal ini, dikarenakan masih banyak guru yang kurang menguasai materi dan pada 
Pengembangan Modul Pelatihan Pedagogical Content Knowledge (PCK) ... | Mega Wulandari \& Ade Iriani

akhirnya memaksakan mengajar materi tertentu dengan metode mengajar yang tidak cocok. Melalui pelatihan PCK, diharapkan para guru dapat menambah pengetahuannya tentang PCK dan mengembangkan kompetensi yang dimilikinya.

\section{Deskripsi Kelemahan Pelatihan Yang Selama Ini Diselenggarakan}

Berdasarkan hasil wawancara dengan YE, RD dan BD, peneliti menyimpulkan beberapa kelemahan pelatihan yang selama ini di selenggarakan, sebagai berikut: 1). Materi yang diberikan kepada peserta pelatihan hanya sekedar print out power point yang akan dipaparkan pembicara. Hal ini, menghambat guru-guru ketika hendak mempelajari kembali materi pelatihan setelah pelatihan selesai. Selain itu, terkadang point penting ataupun paparan yang sebetulnya sangat berguna bagi guru-guru tidak tertulis dan pada akhirnya guru-guru melupakan hal tersebut.; 2). Kebutuhan dan tuntutan setiap guru sangat berbeda-beda. Kebutuhan guru berbeda satu dengan yang lain. Biasanya, guru yang sudah mendekati masa pensiun lebih cenderung pasif dan tidak terlalu antusias dalam mengikuti pelatihan. Selain itu, tuntutan setiap sekolah yang berbeda-beda juga mempengaruhi partisipasi guru dalam mengikuti pelatihan; 3). Seorang guru memiliki tugas mengajar yang berbeda satu dengan yang lain. Selain, tugas mengajar, kegiatan sekolah yang lebih mendesak dan dadakan juga menjadi kendala guru dalam mengikuti pelatihan. Misalnya, kunjungan pengawas sekolah atau kegiatan lainnya. Sehingga, guru tidak memiliki waktu untuk mengikuti kegiatan pelatihan yang diselenggarakan oleh MGMP maupun oleh dinas pendidikan; dan 4). Materi pelatihan disesuaikan dengan program pemerintah. Selama 3 tahun terakhir, pelatihan yang di selenggarakan berkaitan dengan kurikulum 2013. Sebagian guru-guru merasa jika mengikuti satu kali pelatihan saja sebenarnya sudah cukup. Karena, biasanya pelatihan yang berkaitan dengan kurikulum 2013 tidak hanya diselenggarakan dalam waktu satu kali pertemuan. Kelemahan dari pelatihan yang selama ini diselenggarakan, peneliti gunakan sebagai bahan refleksi sehingga mendorong dilakukaannya penelitian dan pengembangan ini.

\section{Pengembangan Modul Pelatihan PCK Potensi dan Masalah}

Pada tahap ini kegiatan yang dilakukan adalah menganalisis potensi dan masalah yang dihadapi guru matematika SMP di Kota Salatiga. Guru yang mengajar mata pelajaran matematika pada jenjang SMP di kota Salatiga, memiliki bekal ilmu yang linier dengan mapel yang diampunya. Guru-guru memiliki kualifikasi akademik pendidikan minimum sarjana dengan program studi yang sesuai mata pelajaran yang diampunya yaitu matematika. Sehingga, guru-guru tersebut memiliki pengetahuan matematika yang menjadi bekal untuk mengajar.

Hasil wawancara dengan salah seorang koordinator MGMP (YE), menunjukkan bahwa banyak guru matematika SMP di Kota Salatiga yang praktik mengajarnya masih kurang. Setiap materi matematika mempunyai karakteristik yang berbeda, sehingga tidak bisa di paksakan dengan model atau metode atau cara mengajar yang sama. Penguasaan materi yang kuat akan membantu guru dalam menentukan strategi mengajar yang akan digunakan. Pemilihan metode atau model atau pendekatan yang tepat akan membantu siswa dengan memahami materi matematika. Sesulit-sulitnya materi matematika jika di ajarkan dengan cara serta strategi mengajar yang tepat akan mudah di terima oleh siswa.

Berdasarkan permasalahan tersebut, perlu dilakukan sebuah pelatihan bagi guruguru matematika yang masih mengalami kesulitan cara mengajar dengan materi tertentu. Oleh karena itu, perlu dilakukan pelatihan mengenai Pedagogical Content Knowledge (PCK) melalui modul pelatihan yang dapat 
Kelola: Jurnal Manajemen Pendidikan, Vol. 5, No. 2, Juli-Desember 2018

membantu guru matematika untuk mengembangkan pengetahuan materi ajar dan pengetahuan mengajar yang dimilikinya.

\section{Pengumpulan Data}

Pengumpulan data dalam penelitian ini dimulai dari studi pendahuluan terkait pelatihan yang sebelumnya diselenggarakan, kompetensi pedagogik dan kompetensi profesional guru matematika SMP dan penguasaan materi serta pemahaman cara mengajar guru matematika melalui wawancara dengan koordinator MGMP dan guru matematika terpilih. Selain itu, dalam tahapan pengumpulan data, dilakukan kajian teoritik tentang PCK, modul pelatihan, dan kompetensi profesional dan kompetensi pedagogik guru matematika. Langkah selanjutnya yaitu mengumpulkan berbagai informasi dan studi literatur yang digunakan untuk perencanaan produk.

\section{Desain Modul Pelatihan}

Perancangan modul pelatihan PCK didasarkan data yang diperleh pada tahap potensi dan masalah, yaitu masih terdapat guru matematika yang mengalami kesulitan terkait pemahaman materi ajar matematika dan pemahaman cara mendidik peserta didik. Hal itu dimaksudkan agar rancangan desain yang telah disusun dapat mengatasi permasalahan yang terjadi di lapangan.

Pada tahapan desain produk peneliti menyusun dan menulis sebuah modul pelatihan Pedagogical Content Knowledge (PCK). Adapun sistematika penulisan modul ini, yaitu (1) bagian awal yang terdiri dari halaman judul, kata pengantar, daftar isi dan glosarium; (2) bagian pendahuluan yang terdiri dari latar belakang, tujuan, peta kompetensi, ruang lingkup, dan petunjuk penggunaan modul; (3) bagian pembelajaran berisi kegiatan pembelajaran yang terdiri dari pengantar, kompetensi dasar, indikator pencapaian, tujuan pembelajaran, uraian materi, aktivitas pembelajaran, latihan atau tugas, rangkuman, tes formatif, umpan balik dan tindak lanjut dan kunci jawaban; (4) bagian evaluasi yang terdiri dari tes dan kunci jawaban; (5) bagian akhir yang terdiri dari penutup, daftar pustaka.

Pada tahapan desain modul pelatihan PCK, juga dilakukan penulisan isi modul sesuai dengan rancangan yang telah di buat. Penulisan modul ini berdasarkan bahan pustaka serta kajian referensi yang berkaitan dengan PCK. Terdapat 3 kegiatan belajar di dalam modul ini, yaitu kegiatan belajar 1 tentang PCK, kegiatan belajar 2 tentang komponen PCK, dan kegiatan belajar 3 tentang penerapan PCK dalam RPP. Pada setiap kegiatan belajar dalam modul pelatihan PCK ini terdapat pengantar, kompetensi dasar, indikator pencapaian, tujuan pembelajaran, uraian materi, aktivitas pembelajaran, latihan atau tugas, rangkuman, tes formatif, umpan balik dan tindak lanjut dan kunci jawaban. Setelah menjadi draftvmodul pelatihan PCK yang utuh, maka dilakukan validasi desain oleh ahli.

\section{Validasi Desain}

Desain produk yang telah dikembangkan berupa draft modul pelatihan PCK, kemudian divalidasi oleh 3 (tiga) orang pakar, yaitu 1). Seorang Ahli Modul; 2) seorang Ahli PCK; dan 3) seorang calon pengguna. Hasil penilaian dari ahli modul pelatihan dan ahli PCK sama, Menempatkan kualitas modul pada skor 68 atau masuk pada kategori cukup baik. Di samping itu ahli modul pelatihan dan ahli PCK memberikan saran dan masukan bagi perbaikan desain modul pelatihan. Sedangkan, calon pengguna memberi skor pada disain modul sebesar 88 atau masuk pada kategori sangat baik.

\section{Revisi Desain}

Tahapan revisi desain dilakukan untuk memperbaiki draft modul yang telah disusun. Hasil validasi oleh ahli menunjukkan bahwa modul dapat digunakan untuk diujicobakan tetapi, harus dilakukan revisi terlebih dahulu. Revisi dilakukan sesuai masukan dan saran para validator. Tahap ini menghasilkan produk berupa Modul Pelatihan PCK bagi guru Matematika SMP. 


\section{Uji Coba Terbatas}

Uji coba produk terbatas dilakukan untuk mengimplementasikan modul PCK yang telah disusun yang telah direvisi. Uji coba terbatas dilaksanakan melalui pelatihan dengan skala kecil. Pelatihan melibatkan beberapa guru matematika SMP di Kota Salatiga Kecamatan Sidorejo. Sebanyak 6 guru matematika SMP dari 3 sekolah yang berbeda-beda terlibat dalam pelatihan ini. Implementasi modul PCK dilaksanakan dalam 1 hari.

Ujicoba modul pelatihan PCK diawali dengan pembukaan yang dilanjutkan dengan pengerjaan pre-test oleh peserta pelatihan. Setelah itu dilanjutkan dengan penjelasan materi dimulai dari kegiatan pembelajaran 1 sampai pada kegiatan pembelajaran 3 . Pelatihan diakhiri dengan pengerjaan post-test oleh peserta pelatihan.

Pre-test dan Post-test dilakukan untuk mengetahui kemampuan peserta pelatihan sebelum dan sesudah mengikuti pelatihan. Peningkatan kompetensi pedagogik dan profesional guru setelah mengikuti pelatihan PCK diketahui dengan membandingkan nilai pre-test dan post-test. Untuk melihat adanya peningkatan setelah pelatihan, maka batas nilai tuntas untuk pre-test dan post-test yaitu 7. Adapun hasil dari pre-test dan post-test dari 6 guru yang mengikuti pelatihan, yaitu sebagai berikut.

Tabel 1. Hasil pre-test dan post-test peserta pelatihan PCK

\begin{tabular}{llcccc}
\hline \multirow{2}{*}{ No } & \multirow{2}{*}{ Nama Guru } & \multicolumn{4}{c}{ Nilai } \\
\cline { 2 - 6 } & & pre-test & Ket & post-test & Ket \\
\hline & CS & 60 & TT & 76 & T \\
\hline. & SY & 48 & TT & 60 & TT \\
\hline \hline & RD & 52 & TT & 76 & T \\
\hline \hline & W & 72 & T & 72 & T \\
\hline \hline & RB & 68 & TT & 80 & T \\
\hline i. & AJ & 76 & T & 72 & T \\
\hline & Rata-rata & \multicolumn{6}{c}{$\mathbf{6 2 , 7}$} & \multicolumn{3}{c}{$\mathbf{7 2 , 7}$} \\
\hline & Persentase & $\mathbf{3 3 , 4 \%}$ & $\mathbf{8 3 , 4 \%}$ \\
\hline
\end{tabular}

Keterangan: $\mathrm{T}=$ Tuntas; $\mathrm{TT}=$ Tidak Tuntas

Tabel 1 menunjukkan bahwa rata-rata pre-test peserta pelatihan adalah 62,7 dimana 2 dari 6 orang peserta pelatihan tuntas dengan presentase $33,4 \%$. Rata-rata post-test peserta pelatihan adalah 72,7 dimana 1 dari 6 orang peserta pelatihan tidak tuntas dengan presentase $83,4 \%$. Data tersebut menegaskan adanya peningkatan kompetensi pedagogik dan kompetensi profesional peserta pelatihan setelah mengikuti pelatihan PCK. Selain meningkatnya nilai, peserta pelatihan juga berhasil menyusun satu RPP. Dari RPP yang di hasilkan maka dapat dilihat penguasaan materi ajar dan cara mengajar peserta pelatihan. Kembali mengingat Komponen PCK sangat membantu peserta pelatihan dalam menyusun RPP. Sehingga, tidak ada lagi kesalahan atau ketidak tepatan di dalam memilih metode mengajar dengan materi tertentu. Dengan berhasilnya peserta pelatihan di dalam menyusun RPP, maka dapat dijadikan bukti akan keberhasilan pelatihan dengan menggunakan modul PCK bagi guru matematika. RPP yang telah di susun oleh enam guru setelah pelatihan dianalisis sesuai dengan komponen PCK yang telah di bagi kedalam dua kompetensi yaitu kompetensi pedagogik dan kompetensi profesional.

Kompetensi pedagogik terbagi menjadi 5 aspek dalam komponen PCK. Adapun kelima aspek tersebut yaitu:

1. Pengetahuan tentang kurikulum

Dari ketiga sekolah yang menjadi subjek penelitian, sudah menggunakan kurikulum 2013. Enam guru yang menjadi subjek penelitian, juga sudah memiliki pengetahuan tentang kurikulum 2013. Selain pengetahuan tentang kurikulum, enam guru tersebut juga memiliki pemahaman yang cukup di dalam menyusun Rencana Pelaksanaan Pembelajaran (RPP).

2. Pengetahuan mengajar

Terdapat dua hal yang penting didalam pengetahuan mengajar guru yaitu tentang motivasi serta proses dan peran guru dalam pembelajaran. Berdasarkan RPP yang disusun oleh keenam guru tersebut, pada kegiatan pendahuluan, guru selalu 
memberikan motivasi kepada siswanya terkait dengan materi yang akan diajarkan. Selain itu, dalam kegiatan inti peran guru dalam proses pembelajaran hanya sebagai fasilitator untuk membantu siswa dalam mencapai tujuan pembelajaran yang diinginkan.

3. Pengetahuan tentang penilaian atau evaluasi Pengetahuan guru terhadap alat evaluasi atau penilaian sangatlah penting dalam proses pembelajaran. Dari RPP yang telah di susun ke enam guru tersebut telah menyusun evaluasi yang akan digunakan. Evaluasi diberikan pada akhir pembelajaran,baik dengan memberikan soal-soal secara langsung didalam kelas ataupun memberikan tugas-tugas lain yang akan di kerjakan siswa.

4. Pengetahuan tentang sumber daya

Berdasarkan RPP yang telah disusun oleh guru, Sumber-sumber materi yang di gunakan tidak hanya berpatokan dari satu buku paket. Guru-guru tersebut mengembangkan materi dari berbagai sumber. Seperti, internet, modul, dan sumber lainnya yang relevan. Selain itu, media pembelajaran yang di gunakan dalam menjelaskan materi sangat beragam, beberapa guru menggunakan power point, video, maupun media audiovisual yang sesuai dengan materi yang akan diajarkan. Sehingga, dapat mempermudah siswa dalam memahami materi yang sedang di ajarkan.

5. Pengetahuan tentang peserta didik

Pada kegiatan refleksi dalam RPP guru dapat memahami setiap respon dari setiap siswa, baik respon positif maupun respon negatif. Sehingga, guru dapat memahami kesulitan belajar yang di alami siswa.

Kompetensi profesional guru terbagi menjadi 2 aspek dalam komponen PCK. Adapun aspek-aspek tersebut yaitu sebagai berikut:
1. Pengetahuan tentang tujuan

Pada kegiatan pendahuluan guru memberikan manfaat atau gambaran yang dikaitkan dengan contoh dalam kehidupan sehari-hari terkait materi yang sedang di ajarkan. Sehingga, diharapkan contoh tersebut dapat mempermudah siswa dalam memahami materi serta dapat menarik siswa di dalam mempelajari materi tertentu yang bermanfaat dalam dunia nyata.

2. Pengetahuan tentang materi

Berdasarkan RPP yang telah disusun, guru telah menguasai materi yang akan di ajarkan. Sehingga, guru dapat menentukan metode, media maupun penilaian yang akan digunakan dalam proses pembelajaran.

Observasi dilakukan untuk mengetahui respon guru sebagai peserta pelatihan dan proses pelaksanaan pelatihan PCK. Hasil observasi menunjukkan bahwa rata-rata skor pelaksanaan pelatihan PCK yang dilaksanakan pada tahap uji coba produk terbatas yaitu sebesar 4,5 dan 4,2 dengan persentase $90 \%$ berkategori sangat baik dan $84 \%$ berkategori baik. Berdasarkan hasil observasi tersebut narasumber telah menguasai materi dan dapat menyampaikan materi dengan baik. Sehingga, peserta pelatihan dapat dengan mudah memahami materi pelatihan dengan menunjukan keaktifan, keseriusan, antusiasme dan keterlibatan peserta pelatih dalam mengikuti pelatihan PCK.

\section{Revisi Produk}

Hasil ujicoba produk terbatas dan masukan-masukan dari peserta dan pelatih dimanfaatkan untuk merevisi produk sehingga tersusun produk Modul Pelatihan PCK bagi Guru Matematika SMP.

\section{Pembahasan}

Pengembangan modul pelatihan PCK melalui 7 (tujuh) tahapan yaitu potensi dan masalah, pengumpulan data, desain produk, validasi desain, revisi desain, uji coba produk terbatas, dan revisi produk ini berangkat dari 
adanya potensi atau masalah sebagaimana dianjurkan oleh Sugiyono (2010: 409).

Dengan mengidentifikasi potensi dan masalah yang ada maka peneliti dapat mencari upaya untuk mengatasi masalah yang ada. Pada tahap ini ditemukan bahwa guru-guru matematika di Kota Salatiga memiliki potensi. Guru-guru tersebut memiliki kualifikasi akademik pendidikan minimum sarjana dengan program studi yang sesuai bidang yang di ampunya yaitu matematika. Sehingga, guruguru tersebut memiliki pengetahuan matematika yang dapat dijadikan bekal untuk mengajar.

Masalahnya belum semua guru menguasai pengetahuan mengajar dan mewujudkannya dalam pembelajaran di kelas. memiliki kendala terkait pemahaman terhadap materi matematika dan cara mengajar siswa dengan karakteristik yang berbeda. Walaupun beberapa guru memiliki pemahaman yang cukup baik terhadap teori belajar, metode mengajar atau media mengajar, namun terkadang guru-guru masih kesulitan dalam mengimplementasikan atau praktik mengajar. Sehingga mereka memiliki pola mengajar yang tetap, padahal tidak semua materi matematika dapat diajarkan kepada siswa dengan metode mengajar yang sama, karena setiap materi memiliki karakteristik yang berbeda-beda. Dengan kata lain penguasaan PCK para guru tersebut lemah.

Kondisi itu sejalan dengan temuan Margiyono (2011) yang menyatakan bahwa masih terdapat beberapa guru yang belum optimal dalam hal penguasaan tentang mengajar dan pemahaman tentang kebutuhan siswa. Padahal menurut Maryono (2016:1) Pedagogical Content Knowledge (PCK) sangat penting dimiliki oleh seorang guru sebagai bekal untuk menciptakan pembelajaran yang bermakna bagi siswa. Sementara Bunawan (2017:83) juga berpendapat bahwa PCK merupakan suatu pengetahuan yang unik bagi guru, yang berkaitan dengan apa yang akan mereka ajarkan. Hal ini menyangkut bagaimana guru mengkaitkan pengetahuan materi pelajaran (apa yang diketahui guru tentang apa yang akan diajarkan) terhadap pengetahuan pedagogi (apa yang diketahui guru tentang mengajar). Kedua pengetahuan tersebut juga dapat dikatakan sebagai dua kompetensi yang harus dimilki guru, dimana pengetahuan pedagogis terkait dengan kompetensi pedagogik sedangkan pengetahuan materi/ konten terkait dengan kompetensi profesional. Berdasarkan, permasalahan yang ada di lapangan peneliti kemudian mengembang kan modul pelatihan PCK bagi guru matematika.

Menurut Sugiyono (2010: 411) tahapan pengumpulan data dilakukan untuk mencari serta mengumpulkan berbagai informasi yang dapat digunakan sebagai bahan untuk perencanaan produk tertentu yang diharapkan dapat mengatasi masalah yang ada. Pada tahap ini peneliti mengumpulkan berbagai informasi dan studi literatur terkait PCK, pelatihan maupun modul dilakukan untuk menemukan konsep-konsep atau landasan-landasan teoretis yang memperkuat dalam menyusun modul PCK. Selain itu, melalui studi literatur peneliti dapat mengetahui langkah-langkah yang paling tepat dalam pengembangan modul pelatihan PCK.

Setelah mengumpulkan banyak data terkait PCK, pelatihan maupun modul maka dilakukan tahapan yang berikutnya yaitu tahap desain produk. Pada tahap ini peneliti mendesain produk yang berupa modul pelatihan PCK guna mengatasi masalah yang ada. Hal itu sejalan dengan pendapat Rahdianyanta (2017:1-2) yang menyatakan bahwa tujuan penulisan modul adalah: 1). memperjelas dan mempermudah penyajian pesan agar tidak terlalu bersifat verbal; 2). mengatasi keterbatasan waktu, ruang, dan daya indera, baik siswa atau peserta diklat maupun guru/instruktur; 3). dapat digunakan secara tepat dan bervariasi; 4). meningkatkan motivasi dan gairah belajar bagi siswa atau peserta 
diklat; 5). mengembangkan kemampuan peserta didik dalam berinteraksi langsung dengan lingkungan dan sumber belajar lainnya; 6). memungkinkan siswa atau peserta diklat belajar mandiri sesuai kemampuan dan minatnya; dan 7). memungkinkan siswa atau peserta diklat dapat mengukur atau mengevaluasi sendiri hasil belajarnya.

Penyusunan modul juga didasarkan pada pandangan Aditia (2013:6) bahwa modul merupakan alat atau sarana pembelajaran yang berisi materi, metode, batasan-batasan materi pembelajaran, petunjuk kegiatan belajar, latihan dam cara mengevaluasi yang dirancang secara sistematis dan menarik, untuk mencapai kompetensi yang di harapkan dan dapat digunakan secara mandiri.

Pada tahap desain, peneliti merancang dan kemudian mengembangkan sebuah rancangan modul pelatihan PCK yang terdiri dari lima bagian yaitu: (1) bagian awal yang terdiri dari halaman judul, kata pengantar, daftar isi dan glosarium; (2) bagian pendahuluan yang terdiri dari latar belakang, tujuan, peta kompetensi, ruang lingkup, dan petunjuk penggunaan modul; (3) bagian pembelajaran berisi kegiatan pembelajaran yang terdiri dari pengantar, kompetensi dasar, indikator pencapaian, tujuan pembelajaran, uraian materi, aktivitas pembelajaran, latihan atau tugas, rangkuman, tes formatif, umpan balik dan tindak lanjut dan kunci jawaban; (4) bagian evaluasi yang terdiri dari tes dan kunci jawaban; (5) bagian akhir yang terdiri dari penutup, daftar pustaka.

Modul pelatihan PCK terdiri dari 3 (tiga) penggalan kegiatan belajar, yaitu kegiatan belajar 1 berisikan tentang PCK, kegiatan belajar 2 tentang komponen PCK, dan kegiatan belajar 3 tentang penerapan PCK dalam RPP. Pada setiap penggalan kegiatan belajar dalam modul pelatihan PCK ini terdapat pengantar, kompetensi dasar, indikator pencapaian, tujuan pembelajaran, uraian materi, aktivitas pembelajaran, latihan atau tugas, rangkuman, tes formatif, umpan balik dan tindak lanjut dan kunci jawaban.

Pada tahap validasi desain, Desain Modul Pelatihan PCK kemudian divalidasi oleh pakar. Validasi dilakukan oleh 1). Ahli Pengembangan Modul; 2). Ahli PCK; dan 3). Calon pengguna. Hasil validasi oleh ahli pengembangan modul dan ahli PCK memiliki persentase yang sama, yaitu sebesar $68 \%$ atau termasuk kategori cukup baik dengan keterangan layak digunakan dengan revisi. Selain itu, terdapat beberapa saran dan masukan yang berbeda-beda dari ahli modul dan ahli PCK. Adapun masukan dan saran dari validator ahli modul pelatihan yaitu 1). Rumusan indikator dan tujuan harus operasional; 2). Menggunakan kata kerja dengan tingkat kognitif yang lebih tinggi; 3). Menyesuaikan kegiatan belajar dan evaluasi dengan tingkat kognitif yang tinggi. Sedangkan, masukan dan saran dari validator ahli PCK yaitu 1). Menambah uraian materi; 2). Memperhatikan kembali hirarki CK, PK, dan PCK; 3). Menambah contoh yang lebih sederhana; 4). Menghubungkan PCK, K-13 dan peran PCK dalam RPP. Persentase penilaian dari ahli calon pengguna sebesar $88 \%$ pada kategori sangat baik. Adapun keterangan dari validator calon pengguna yaitu baik dan sudah dapat di gunakan.

Berdasarkan, penilaian dari ketiga ahli tersebut, maka dilakukan revisi modul pelatihan PCK, sesuai dengan masukan dan saran yang diberikan. Setelah dilakukan revisi maka Modul Pelatihan PCK ini siap untuk diujicobakan.

Tahapan uji coba terbatas atas Modul yang telah disusun dilakukan melalui pelatihan. Pelatihan ini melibatkan 6 guru dari 3 SMP yang berbeda. Pelatihan dilaksanakan selama 1 hari. Pada tahapan implementasi juga di lakukan Pre-test dan Post-test untuk mengetahui kemampuan peserta pelatihan sebelum dan sesudah mengikuti pelatihan. Hasil rata-rata Pre-test sebesar 62,7 dan rata- 
rata post-test peserta pelatihan adalah 72,7 . Berdasarkan, hasil tersebut maka modul pelatihan PCK memiliki dampak bagi peserta pelatihan. Sehingga, modul pelatihan tersebut dapat digunakan dalam upaya meningkatkan kompetensi guru. Hasil ini sejalan dengan hasil penelitian Giarti (2016) yang menunjukkan bahwa pengembangan modul pelatihan dapat meningkatkan kompetensi guru SD. Hasil penelitian ini juga sejalan dengan penelitian Sumarah, dkk (2017) juga menunjukkan bahwa modul pelatihan sangat membantu guru didalam memahami materi tertentu. Selain itu, hasil penelitian ini juga sejalan dengan hasil penelitian Budiyono, dkk (2014) yang juga menunjukkan bahwa modul pelatihan yang diberikan kepada guru dapat meningkatkan kompetensi pedagogik dan pada akhirnya juga akan meningkatkan kompetensi profesional para guru.

Walau berbeda subyek mata pelajarannya pengembangan modul PCK ini juga berfungsi sama seperti modul hasil pengemangan Resbiantoro (2015) di mana Modul pedagogical content knowledge (PCK) yang dikembangkan layak diguna kan oleh guru dan calon guru untuk menunjang dan memberikan alternatif referensi untuk guru dan calon guru dalam melaksanakan pembelajaran. Pengembangan modul PCK yang disusun oleh Resbiantoro (2015) berkaitan dengan matapelajaran fisika serta materi tertentu, sedangkan, pengembangan modul pelatihan PCK yang disusun peneliti diperuntukkan bagi guru mapel matematika pada jenjang SMP.

\section{SIMPULAN DAN SARAN}

\section{Simpulan}

Berdasarkan hasil penelitian dan pembahasan hasil penelitian yang telah dipaparkan, dapat disimpulkan sesuai dengan rumusan masalah penelitian dan pengembangan sebagai berikut:

(1) Pelatihan bagi guru matematika SMP selama ini difokuskan pada sosialisasi
Kurikulum 2013. Pelatihan mengenai PCK belum pernah diselenggarakan oleh MGMP maupun dinas pendidikan Kota Salatiga.;

(2) Kelemahan pelatihan yang selama ini diselenggarakan adalah: 1). Materi sekedar print out power point yang akan dipaparkan pembicara; 2). Kebutuhan dan tuntutan guru yang berbeda-beda, sehingga menghambat guru berpartisipasi dalam pelatihan-pelatihan; 3) waktu pelatihan bertabrakan dengan kegiatan guru di sekolah; dan 4) materi pelatihan selama ini hanya berkaitan dengan $\mathrm{K}-13$, sehingga guru-guru merasa cukup satu kali mengikuti pelatihan;

(3) Modul pelatihan PCK yang telah dikembangkan memperoleh skor 68 dari ahli modul dan ahli PCK sehingga masuk kategori cukup baik. Sedangkan, skor penilaian dari calon pengguna sebesar 88 atau sangat baik. Dalam uji coba modul pelatihan PCK, skor rata-rata post-test peserta pelatihan adalah 72,7 sedang prosentase ketuntasan peserta pelatihan sebesar $83,4 \%$. Dengan demikian modul ini layak untuk digunakan.

\section{Saran}

Berdasarkan kesimpulan yang telah dipaparkan, dapat disampaikan saran agar, Dinas Pendidikan Kota Salatiga lebih mengkaji ulang kebutuhan dan hambatan yang dihadapi guru di lapangan, sehingga dapat dilakukan pelatihan-pelatihan yang disesuaikan dengan hambatan yang ada. Kepala sekolah disarankan dapat mendukung danmemberikan motivasi kepada setiap guru untuk berpartisipasi pada pelatihan yang dapat menunjang serta menambah pengetahuan guru di bidangnya. Bagi guru, disarankan untuk selalu meningkatkan minat di dalam belajar secara mandiri dengan modul pelatihan PCK yang telah di berikan, serta menambah referensi dari sumber-sumber lain. 
Kelola: Jurnal Manajemen Pendidikan, Vol. 5, No. 2, Juli-Desember 2018

\section{UCAPAN TERIMAKASIH}

Terimakasih yang tulus diberikan kepada Dr. Bambang Suteng Sulasmono, M.Si yang menjadi Pembimbing II dalam penulisan Tesis yang substansinya kemudian tersaji dalam bentuk artikel ini.

\section{DAFTAR PUSTAKA}

Aditia, M. Taufik, dkk. 2013. Pengembangan Modul Pembelajaran Berbasis Sains, Lingkungan, Teknologi, Masyarakat Dan Islam (Salingtemasis). Jurnal Scientiae Educatia Volume 2 Edisi 2.

Aminah, Neneng. 2014. Implementasi Pedagogical Content. Universitas Swadaya Gunung Jati Cirebon. Jurnal Euclid, ISSN 2355-17101, vol.1, No.1, pp. 1-59

Budiyono Herman, dkk. 2014. Pengembangan

Bahan Pelatihan Desain Sistem Pembelajaran Bagi Guru Bahasa Indonesia SMA. Tekno-Pedagogi Vol. 4 No. 1 Maret 2014 : 7-14.

Bunawan, Wawan dan Yarni Laoli. 2017. Implementasi Pedagogical Content Knowledge (PCK) Berbasis Inkuiri Terbimbing Terhadap Hasil Belajar Siswa. Jurnal Inovasi Pembelajaran Fisika. e-issn 2549-8258, p-issn 23374624.

Damawati, Nyoman Ari. 2015. Pemahaman Terhadap PCK (Pedagogical Content Knowledge) Untuk Meningkatkan Profesionalisme Guru. Seminar Nasional ALFA IV.

Departemen Pendidikan Nasional. 2002, Teknik Belajar dengan Modul, Jakarta: Dirjen Pendidikan Dasar dan Menengah.

Giarti, Sri. 2016. Pengembangan Modul Pelatihan Penulisan Karya Ilmiah Berbasis Andragogi Berbantuan CSM
MOODLE. Kelola: Jurnal Manajemen Pendidikan, Vol. 3 No.1, 2016.

Hanggara, Agie. 2015. Studi Pedagogical Content Knowledge (PCK) Guru. Universitas Pendidikan Indonesia. Diakses dari: http://repository.upi.edu/23967/4/D_IP S_1202032_Chapter1.pdf

Kamil, Mustofa. 2010. Model Pendidikan dan Pelatihan. Bandung: Alfabeta

Koehler, M. J., Mishra, P., Ackaoglu, M.,\&Rosenberg, J. M. 2013. The Technological Pedagogical Content Knowledge Framework for Teachers and Teacher Educators. Commonwealth Educational Media Centre for Asia.

Margiyono, Iis, dkk. 2011. Deskripsi PCK Guru Pada Bahasan Tentang Bilangan Rasional. Diakses dari: http://eprints.uny.ac.id/945/1/P\%20\%2013.pdf

Maryono. 2016. Profil Pedagogical Content Knowledge (PCK) Mahasiswa Calon Guru Matematika Ditinjau Dari Kemampuan Akademiknya. Jurnal Review Pembelajaran Matematika. JRPM, 2016, 1(1), 1 - 16

Peraturan Pemerintah Nomor 74 Tahun 2008 Tentang Guru

Rahdiyanta Dwi. 2017. Teknik Penyusunan Modul. Diakses dari: http:/ / staff.uny.ac.id/sites/defaulf les/penelitian/drdwirahdiyantamp d/20-teknikpenyusunanmodul.pdf.

Resbiantoro, dkk. 2015. Pengembangan Modul Pedagogical Content Knowledge Fisika Pada Materi Hukum Gravitasi Newton Untuk SMA Kelas XI. Jurnal Inkuiri ISSN: 2252-7893, Vol 4, No. I, 2015 (hal 121-130). 
Pengembangan Modul Pelatihan Pedagogical Content Knowledge (PCK) ... | Mega Wulandari \& Ade Iriani

Rosyid, Abdul. 2016. Technological Pedagogical Content Knowledge: Sebuah Kerangka Pengetahuan Bagi Guru Indonesia Di Era Mea. Prosiding Seminar Nasional Inovasi Pendidikan

Shulman. 1986. Those Who Understand: Knowledge Growth in Teaching. Educational Research. Vol.15(2): 4-14.

Sugiyono. 2010. Metode Penelitian Pendidikan Pendekatan Kuantitatif, Kualitatif, dan R \& D. Bandung : Alfabeta.

Sumarah, IG. Esti, dkk. 2017. Pengembangan Modul Pelatihan Model Pembelajaran
Van Hiele Dalam Konteks Pendidikan Karakter Guru SD. Jurnal Penelitian Vol. 21 No. 1 Mei 2017. ISSN 14105071.

Suminawati, dkk. 2018. Implementasi PCK Terhadap Kemampuan Kognitif Siswa. Online. https://nanopdf.com/download/imp lementasi-pedagogical-conten_pdf.

Susilowati, dkk. 2015. Analisis PCK Guru IPA SMP Kelas VIII Dalam Implementasi Kurikulum 2013. Jurnal Pendidikan Matematika dan Sains Tahun III, No. 1, Juni 2015 